\title{
Upaya Meningkatkan Kemampuan Membaca Lancar dengan Menerapkan Model Pembelajaran Cooperative Learning Tipe Make a Match Siswa Kelas III Semester 2 SD Negeri 64/IV Kota Baru Jambi
}

\author{
Sawiyah \\ Guru SD Negeri 64/IV Kota Baru Jambi \\ Email: sawiyahjambi@gmail.com
}

\begin{abstract}
This research is backed up that the learning outcomes of elementary School 64/IV Jambi city is still low 58.69 with its submission to only 17.39\%, which is only 4 people from 23 class III students elementary School 64/IV Jambi City. This is due to the lack of active participation and student involvement during the learning process. In addition before being addressed this PTK teacher has not used the Make A Match type method, just more using the lecture method. Teachers need to implement learning methods that can encourage student involvement in learning. The Make A Match type method is one of the methods that can fulfill these expectations. The purpose of this research is to know whether the Make A Match type method can increase learning activity and student learning outcomes. This research is a class action research (PTK) with the subject of research is a class III students of even semester (2) Elementary School 64/IV Kota Jambi. The methods of data collection that are tested in this study are the methods of testing and observation. Collected Data is analyzed with qualitative descriptive analysis. The results showed that there was an increase in student activity and learning outcomes after receiving learning with the Make A Match type method. The results of increased learning outcomes and student activity will experience an increase in the reading smoothly for students of class III $D$ SD 64/IV of Jambi City. The increase in the I cycle of 64.58 Learning management while the II cycle has increased to be $89.58 \%$ very good category. If the management is very good certainly affects the outcome of learning and activity of students that is cycle I activity students 70.58 enough categories while cycle II multiply the increase to 92.83 category very well. Further to the results of learning in the I 65.22 cycle category is enough while the II cycle is experiencing a peningktan to 79.80 good categories. It can be concluded that using a problem-based learning method can improve learning activities and student learning outcomes.
\end{abstract}

Keywords: Seamless reading ability, Cooperative Learning type Make a Match

\section{PENDAHULUAN}

Bahasa Indonesia adalah mata pelajaran pokok di Sekolah yang digunakan untuk mengasah keterampilan siswa seperti keterampilan berbicara, menyimak, mendengar,dan menulis. Siswa di sekolah dituntut untuk dapat menggunakan berbahasa Indonesia dengan benar, membaca maupun menulis.

Awal dari sebuah proses belajar, tidak lepas dari membaca dan menulis. Pada siswa sekolah dasar membaca dan menulis merupakan hal pokok yang harus dikuasai siswa, karena disinilah tindak lanjut proses pembelajaran. Sebagaimana yang dikemukakan oleh Tarigan (1990:136) bahwa keterampilan membaca dan menulis masih banyak menunjukkan kelemahan. Dengan membaca diharapkan akan memperoleh suatu pengetahuan yang bisa dikembangkan dalam bentuk tulisan ataupun karangan

Fakta dibeberapa sekolah menyatakan bahwa pembelajaran Bahasa Indonesia masih menyulitkan bagi siswa karena masih banyak yang ditemukan beberapa hal seperti: siswa sukar mencapai hasil belajar yang baik, siswa suka berjalan di kelas, siswa suka bercerita dengan teman, siswa tidak fokus dalam belajar, dan siswa belum mampu membaca lancar.

Permasalahan di atas disebabkan oleh kurangnya penggunaan metode yang belum tepat, penggunaan alat peraga yang kurang menarik, kurangnya perhatian dari orang tua, dan kurangnya latihan yang dilakukan oleh siswa. Diantara masalah tersebut yang paling esensial adalah Siswa belum mampu membaca lancar. Hasil penilaian membaca lancar ini siswa disapkan teks bacaan kemudian menjawab pertanyaan yang berkaitan dengan teks bacaan tesrebut. Apabila siswa menjawabnya banyak salaah dengan waktu yang telah ditentukan, maka hasil siswa tersebut brdampak akan rendah.

Adapun hasil penilaian dari mata pelajaran Bahasa Indonesia pada membaca lancar kelas III.D SDN 64/IV rata-rata hasilnya belum mencapai KKM sekolah yaitu 75 . Hasil nilai rata-rata untuk membaca dengan lancar hanya 54,40 dari 25 siswa kelas III. SD Negeri 64/IV Kec. Kota Baru Jambi.

Masalah tersebut tentu tidak dapat dibiarkan karena berdampak kepada proses pembelajaran tidak menarik, siswa belajar tidak aktif, tujuan pembelajaran tidak tercapai, dan tidak mendapatkan hasil yang diharapkan.

Teori membaca ada beberapa macam diantaranya adalah membaca nyaring maksudnya adalah proses melisankan dengan menggunakan suara, intonasi,tekanan secara tepat, serta pemahaman makna bacaan oleh pembaca. Sebagai guru kelas penulis mencoba mencarikan alternatif solusinya yaitu melalui dengan cara merubah strategi pembelajaran, menggunakan metode demonstrasi,dan menggunakan model pembelajaran Mencari Pasang.

\section{Kajian Teori \\ Hakikat Pembelajaran Bahasa Indonesia di SD}

Bahasa Indonesia mempunyai kedudukan sebagai nasional dan bahasa negara. Berhubungan dengan hal itu maka perlu adanya suatu pembelajaran Bahasa Indonesia. Secara keseluruhan mata pelajaran Bahasa Indonesia di SD berfungsi untuk mengembangkan kemampuan bernalar, berkomunikasi, dan mengungkapkan pikiran dan perasaan serta persatuan dan kesatuan bangsa.

Pengajaran bahasa Indonesia bertujuan untuk mengembangkan kemampuan menggunakan bahasa 
Indonesia dalam segala fungsinya, yaitu sebagai sarana komunikasi, sarana berfikir/bernalar, sarana persatuan,dan sarana kebudayaan. (Sabarati Akhadiah M.K., Maidar G.Arsjad, Sakura H.Ridwan, Zulafahnur Z.F., Mukti U.S., 1991:10)

Kemudian pembelajaran bahasa Indonesia juga mempunyai sasaran, sasaran pembinaan bahasa Indonesia bagi siswa SD ialah (1) agar siswa memiliki kemampuan berbahasa Indonesia yang baik dan benar, (2) dapat menghayati bahasa dan satra Indonesia (Sabarti Akhadiah M.K., et al, 1991:11)

\section{Hasil Belajar}

Hasil belajar peserta didik pada hakekatnya adalah perubahan tingkah laku. Tingkah laku sebagai hasi belajar dalam pengertian yang luas mencangkup bidang kognitif, afektif dan psikomotorik" (Sudjana,2010:3). Hasil belajar juga didefinisikan sebagai proses untuk menentukan nilai belajar peserta didik melalui kegiatan penilaian dan/atau pengukuran hasil belajar. Berdasarkan pengertian evaluasi hasil belajar kita dapat menengarai tujuan utamnya adalah untuk mengetahui tingkat keberhasilan yang dicapai oleh peserta didik setelah mengikuti suatu kegiatan pembelajaran. Di mana tingkat keberhasilan tersebut kemudian ditandai dengan skala nilai berupa huruf atau angka atau symbol (Dimyati dan Mudjiono, 2009:200).

Hasil belajar mempunyai hubungan yang erat dengan belajar itu sendiri.Untuk mengetahui sampai mana perubahan yang terjadi pada diri sendiri baik itu perubahan tingkah laku dan kecakapan dapat dilihat dari hasil belajarnya. Secara umum untuk mengetahui hasil belajar peserta didik dapat diklasifikasikan kedalam tiga ranah hasil belajar, ranah kognitif, ranah afektif, dan ranah psikomotorik. Jadi hasil belajar dapat dikatakan sebagai pengetahuan yang dikuasai oleh peserta didik sebagai hasil dari kemampuan penyerapan pengetahuan dalam proses belajar mengajar baik secara perorangan maupun secara kelompok yang diintegrasikan kedalam pelajaran. Untuk mengukur tingakat hasil belajar berupa hasil tes prestasi.

\section{Pengertian Membaca}

Menurut Vacca (1991:172)," Membaca adalah proses aktif dari pikiran yang dilakukan oleh mata terhadap bacaan". Dalam kegiatan membaca,pembaca memproses informasidari teks yang dibaca untuk memperoleh makna. Membaca merupakan kegiatan penting dalam kehidan sehari-hari, karena membaca tidak hanyauntuk memperoleh informasi,tetapi berfungsi sebagai alat untuk memperluas pengetahuan bahasa seseorang.

Menurut Harris dan Sipay (1980:10" Membaca sebagai suatu kegiatan yang memberikan respon makna secara tepat terhadap lambang verbal yang tercetak atau yang tertulis". Pemahaman atau makna dalam membaca lahir dari interaksi antara persepsi terhadap simbol grafis dan keterampilan bahasa serta pengetahuan bahasa. Dalam interaksi ini, pembaca berusaha menciptakan kembali makna sebagai mana makna yang ingin disampaikan oleh penulis dan tulisanya.

Berdasarkan pernyataan di atas, dalam konteks penelitian dapat disimpulkan bahwa membaca merupakan sebuah proses yang melibatkan kemampuan visual dan kemampuan kognisi yang diperlukan untuk memberikan lambing-lambang huruf agar dapat dipahami danbermakna bagi pembaca.

\section{Keterampilan Membaca Lancar}

Keterampilan membaca lancar merupakan salah satu bagian kegiatan membaca, kegiatan ini disebut juga membaca cepat. Muchlishoh (1992:153) mengatakan membaca cepat yaitu jenis membaca yang diberikan dengan tujuan agar para siswa dalam waktu singkat dapat membaca secara lancar, dapat memahami isinya. Menurut Supriyadi (1995:127) menyatakan" keterampilan membaca yang sesungguhnya bukan hanya sekedar kemampuan menyuarakan lambang tertulis dengan sebaik-baiknya namun lebih jauh adalah kemampuan memahami dari apa yang tertulis dengan tepat dan cepat".

\section{Model-model Pembelajaran Membaca}

Membaca lancar merupakan salah satu keterampilan membaca yang perlu ditumbuhkembangkan dalam diri siswa semenjak dini. Karena membaca lancar sangat penting dimiliki oleh siswa guna menghadapi perkembangan teknologi informasi yang semakin hari semakin canggih. Kemampuan lancar dapat ditingkatkan melalui latihan yang dilaksanakan secara bertahap dan terus menerus.

Banyak ahli yang menawarkan berbagai model pembelajaran agar seseorang mampu dan memiliki kemampuan membaca lancar. Salah satunya adalah model pembelajaran Mencari Pasangan yang akan mengantarkan seseorang kepada kemampuan membaca cepat dan lancar yang maksimal.

\section{Pengertian Model Cooperative Learning Tipe Make A Match}

Cooperative learning memiliki berbagai jenis atau tipe, salah satunya adalah tipe make a match. Menurut Lie (2002: 55) teknik belajar mengajar mencari pasangan (make a match) dikembangkan oleh Lorna Curran (1994). Salah satu keunggulan teknik ini adalah siswa mencari pasangan sambil belajar mengenai suatu konsep atau topik dalam suasana yang menyenangkan. Hal ini sejalan dengan pendapat Isjoni (2007: 77) menyatakan bahwa make a match merupakan model pembelajaran mencari pasangan sambil belajar konsep dalam suasana yang menyenangkan.

Komalasari (2010: 85) menyatakan bahwa model make a match merupakan model pembelajaran yang mengajak siswa mencari jawaban terhadap suatu pertanyaan atau pasangan dari suatu konsep melalui suatu permainan kartu pasangan dalam batas waktu yang ditentukan. Sedangkan menurut Huda (2012: 135) make a match merupakan salah satu pendekatan konseptual yang mengajarkan siswa memahami konsepkonsep secara aktif, kreatif, efektif, interaktif, dan menyenangkan bagi siswa sehingga konsep mudah dipahami dan bertahan lama dalam struktur kognitif siswa.

Berdasarkan pendapat para ahli di atas, penulis menyimpulkan bahwa model cooperative learning tipe make a match merupakan model pembelajaran 
kelompok yang mengajak siswa memahami konsepkonsep melalui permainan kartu pasangan. Permainan tersebut dibatasi waktu yang telah ditentukan dalam suasana belajar yang menyenangkan.

\section{Kelebihan dan Kekurangan Model Cooperatif Learning Tipe Make A Match.}

Setiap model dalam pembelajaran memiliki kelebihan dan kekurangan ketika diterapkan dalam pelaksanaan pembelajaran. Menurut Lie (2002: 46) kelebihan dan kekurangan model pembelajaran kelompok berpasangan adalah sebagai berikut: 1) Kelebihan: a) Meningkatkan partisipasi siswa. b) Cocok untuk tugas sederhana. c) Lebih banyak kesempatan untuk kontribusi masingmasing anggota kelompok. d) Interaksi lebih mudah. e) Lebih mudah dan cepat membentuknya. 2) Kekurangan: a) Banyak kelompok yang melapor dan perlu dimonitor. b) Lebih sedikit ide yang muncul. Berdasarkan pendapat yang telah dikemukakan Lie di atas, model cooperative learning tipe make a match memiliki banyak kelebihan dan kekurangan. Guru harus berupaya memaksimalkan pembelajaran agar tidak terjadi kesenjangan di dalam kelas.

\section{Langkah-langkah Cooperative Learning Tipe Make a Match}

Setiap model pembelajaran memiliki langkahlangkah dalam pelaksanaaannya, agar mudah diterapkan dalam pembelajaran. Menurut Komalasari (2010: 83-84) langkah-langkah penerapan model cooperative learning tipe make a match adalah sebagai berikut: 1) Guru menyiapkan beberapa kartu yang berisi beberapa konsep atau topik yang cocok untuk sesi review, sebaliknya satu bagian kartu soal dan bagian lainnya kartu jawaban. 2) Setiap siswa mendapat satu buah kartu. 3) Tiap siswa memikirkan jawaban/soal dari kartu yang dipegang. 4) Setiap siswa mencari pasangan yang mempunyai kartu yang cocok dengan kartunya (soal jawaban). 5) Setiap siswa yang dapat mencocokkan kartunya sebelum batas waktu diberi poin. 6) Setelah satu babak, kartu dikocok lagi agar tiap siswa mendapat kartu yang berbeda dari sebelumnya. 7) Demikian seterusnya. 8) Kesimpulan/penutup.

Model cooperative learning tipe make a match merupakan model pembelajaran kelompok yang mengajak siswa memahami konsep-konsep melalui permainan kartu pasangan, permainan ini dibatasi waktu yang telah ditentukan dalam suasana belajar yang menyenangkan. Adapun langkah-langkah model cooperative learning tipe make a match harus dilaksanakan secara sistematis, pelaksanaannya diawali dengan tahap persiapan, pembagian kartu pertanyaan atau jawaban, mencari dan menemukan pasangan, pemberian penghargaan, dan penyimpulan.

Berdasarkan uraian di atas sesuai dengan pendapat Anita Lie (2008:56 ) bahwa pembelajaran mencari pasangan merupakan teknik belajar yang memberi kesempatan siswa untuk bekerja sama dengan orang lain. Maka penulis mencoba menggunakan model pembelajaran tersebut kepada siswa supaya dapat meningkatkan kemampuan siswa dalam membaca lancar.

\section{Kemampuan Membaca}

Kemampuan membaca adalah kesanggupan, kecakapan, kita berusaha dengan diri sendiri (Poerwadarminta,1982:182). Jadi kemampuan adalah mampu melaksanakan suatu, dalam hal ini kemampuan yang dimaksudkan adalah untuk melaksanakan sesuatu dengan baik dan cermat.Jadi dalam kaitannya dengan kemampuan membaca disini adalah suatu yang dimiliki dan melekat pada diri seseorang, baik berupa pikiran dan perubahan yang timbul dari kesadaran.

\section{Penelitian Yang Relevan}

Hasil Penelitian Terdahulu dengan Judul Metode Hasil Penelitian

1) M. Agus (2014) Analisis Penerapan Model Pembelajaran Kooperatif Tipe Make a Match (studi deskriptif mata pelajaran ekonomi sub pokok materi perbedaan antara ekonomi mikro dan ekonomi makro di kelas III SD Mekarwangi Lembang Kabupaten Bandung Barat Penelitian Deskriptif Kegiatan belajar mengajar menggunakan model pembelajaran kooperatif metode diskusi teknik make a match lebih baik Sama-sama menggunakan model pembelajaran kooperatif learning tipe make a match Perbedaan tidak menggunakan variable (y) dan metode penelitiannya berbeda

2) Mery irawan (2013) Pengaruh model pembelajaran kooperatif tipe make a match terhadap hasil belajar siswa Eksperimen Diperoleh hasil bahwa melalui penerapan model pembelajaran make a match terjadi peningkatan hasil belajar siswa dalam mata pelajaran akuntansi Sama-sama menggunakan model pembelajaran kooperatif tipe make a match Metode penelitiannya, objek yang diteliti berbeda dan operasionalnya berbeda.

\section{Hipotesis Tindakan}

Hipotesis yang diajukan dalam penelitian ini adalah: implementasi model pembelajaran make a macth dapat meningkatkan kemampuan membaca lancar pada siswa kelas III semester 2 SD negeri 64/IV Kota Jambi.

\section{METODE PENELITIAN Jenis Penelitian}

Penelitian ini merupakan penelitian tindakan (action research), karena penelitian dilakukan untuk memecahkan masalah pembelajaran di kelas. Penelitian ini juga termasuk penelitian deskriptif, sebab menggambarkan bagaimana suatu teknik pembelajaran diterapkan dan bagaimana hasil yang diinginkan dapat dicapai.

\section{Subjek Penelitian}

Subjek penelitian ini adalah semua siswa kelas III.D SDN 64/IV Kota Jambi dengan jumlah siswa 28 orang, laki-laki 15 orang dan perempuan 13 orang. Kebanyakan siswa berasal dari berbagai daerah.Orang tua mereka ada yang bekerja sebagai buruh harian, ojek, petani, berjualan, dan sebagian kecil pegawai negeri/ TNI/ Polri. Keadaan ini memungkinkan siswa kurang dikontrol oleh orang tuanya untuk belajar di rumah sehingga siswa mengalami kurangnya kemampuan untuk membaca dengan lancar. 


\section{Lokasi dan Waktu Penelitian}

Lokasi penelitian ini di kelas III.C SDN 64/IV Kota Jambi. Jumlah murid di kelas III.D berjumlah 25 siswa. Selanjutnya untuk jumlah seluruhnya 179 siswa, lakilaki 94 siswa perempuan 85 siswa. Kepala Sekolah 1 orang, guru kelas 7 orang, guru agama islam 1 orang, guru PJOK 1 orang, tenaga administrasi sekolah 1 orang, dan penjaga sekolah 1 orang

\section{Teknik Pengumpulan Data}

Teknik pengumpulan data merupakan langkah yang paling utama dalam penelitian, karena tujuan utama dari penelitian adalah mendapatkan data. Tanpa mengetahui teknik pengumpulan data, maka peneliti tidak akan mendapatkan data yang memenuhi standar data yang ditetapkan. Untuk memperoleh data yang diinginkan peneliti menggunakan beberapa metode, diantaranya adalah metode tes, unjuk kerja, dan observasi.

\section{Teknik Analisis Data}

Teknik analisis data yang digunakan dalam penelitian ini adalah dengan mencermati atau menelaah , menguraikan, dan mengkaitkan setiap informasi yang terkait dengan kondisi awal, proses belajar, dan hasil pembelajaran untuk memperoleh simpulan tentang keberhasilan tindakan perbaikan pembelajaran. Data yang diperoleh dapat menggunakan data kuantitatif misal hasil tes dan data kualitatif misal keaktifan siswa dalam proses pembelajaran.

\section{Teknik Analisis data Pengelolaan Pembelajaran Guru.}

Teknik analisis data pengelolaan pembelajaran guru dalam menggunakan model pembelajaran cooperative learning make a macth dilakukan dengan menggunakan teknik analisis kualitatif, karena data yang diperoleh berbentuk kategori/kualitatif. Teknik analisis data kinerja guru pada setiap siklus dilakukan dengan cara mengisi lembar pengamatan 1. Jumlah skor lembar penilaian 1 kemudian dipersentase dengan rumus sebagai berikut:

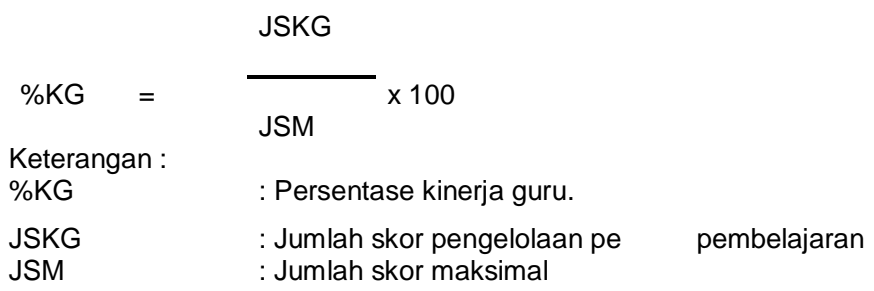

Selanjutnya dari hasil penghitungan rumus tersebut diklasifikasikan berdasarkan kategori pengelolaan pembelajaran guru yaitu sebagai berikut:

Tabel 1. Klasifikasi Persentase Pengelolaan Pembelajaran Guru

\begin{tabular}{ccc}
\hline No & Persentase & Kategori \\
\hline 1 & $89 \%-100 \%$ & Sangat baik \\
2 & $77 \%-88 \%$ & Baik \\
3 & $63 \%-76 \%$ & Cukup \\
4 & $50 \%-62 \%$ & Kurang \\
5. & $49 \%$ ke bawah & Tidak baik \\
\hline
\end{tabular}

Teknik analisis data aktivitas belajar siswa.

Teknik analisis data aktivitas belajar siswa dalam pembelajaran Bahasa Indonesia tentang membaca lancar dilakukan dengan menggunakan teknik analisis kualitatif, karena data yang diperoleh berbentuk kategori/kualitatif. Teknik analisis data aktivitas belajar siswa pada setiap siklus dilakukan dengan cara mengisi lembar pengamatan 2 dan kemudian skornya dijumlah. Jumlah skor kemudian dipersentase dengan rumus sebagai berikut:

\section{JSAS}

\%AS $=\quad \begin{aligned} & \text { JSM } \\ & \text { Keterangan : }\end{aligned}$
\%AS $\quad:$ Persentase aktivitas belajar Bind
JSS $\quad:$ Jumlah skor aktifitas belajar Bind
JSM $\quad:$ Jumlah skor maksimal

Selanjutnya dari hasil penghitungan rumus tersebut diklasifikasikan berdasarkan kategori kinerja guru, yaitu sebagai berikut:

Tabel 2. Klasifikasi Persentase Aktivitas Siswa

\begin{tabular}{ccc}
\hline No & Persentase & Kategori Aktifitas Siswa \\
\hline 1 & $90 \%-100 \%$ & Sangat aktif \\
2 & $79 \%-89 \%$ & Aktif \\
3 & $68 \%-78 \%$ & Cukup \\
4 & $59 \%-69 \%$ & Kurang Aktif \\
5. & $58 \%$ kebawah & Tidak aktif \\
\hline
\end{tabular}

Teknik Analisis data Hasil Belajar Siswa

Teknik analisis data hasil belajar siswa dalam pembelajaran Bahasa Indonesia dengan materi membaca lancer dilakukan dengan peneliti melakukan penjumlahan nilai yang diperoleh peserta didik yang selanjutnya dibagi dengan jumlah peserta didik yang ada di kelas tersebut sehingga diperoleh rata-rata tes formatif dapat dirumuskan menggunakan teknik analisis kualitatif, karena data yang diperoleh berbentuk kategori/kualitatif. Jumlah skor kemudian dipersentase dengan rumus sebagai berikut:

Tabel 3 Klasifikasi Persentase Hasil Belajar Siswa

\begin{tabular}{ccc}
\hline No & Persentase & Kategori Hasil Nilai Belajar \\
\hline 1 & $89 \%-100 \%$ & Sangat Baik \\
2 & $77-88 \%$ & Baik \\
3 & $63 \%-76 \%$ & Cukup \\
4 & $50 \%-62 \%$ & Kurang \\
5 & $49 \%$ kebawah & Sangat Kurang \\
\hline
\end{tabular}

\section{Prosedur Penelitian}

Penelitian ini merupakan Penelitian Tindakan Kelas (PTK), adapun tahapan yang akan dilakukan dalam PTK ini menggunakan model yang dikembangkan oleh Kurt Lewin. Model Kurt Lewin seperti disebutkan dalam Dikdasmen(2003:18) bahwa tahap-tahap tersebut atau biasa disebut siklus(putaran) terdiri 4 komponen yang meliputi:(a) perencanaan (planning), (b) aksi atau tindakan (Acting), (c) observasi(observing), dan refleksi (reflecting). Sedangkan prosedur pelaksanaan penelitian ini meliputi 2 siklus terdiri dari perencanaan, tindakan pengamatan, dan refleksi. 


\section{HASIL DAN PEMBAHASAN}

\section{Gambaran Umum Lokasi Penelitian}

Lokasi penelitian tindakan kelas ini adalah di SD Negeri 64/IV Kec. Kota Baru Jambi. Lokasi sekolah tersebut Jl. Ir H. Juanda RT.33 Kelurahan Kota Jambi . Sekolah ini mulai beroperasional sejak dikeluarkannya surat keputusan no. 452 tahun 2017 dan belum terakriditasi. Rombongan belajar SD Negeri 64/IV Kota Jambi sebanyak 9 rombel, 1 ruang kepala sekolah, dan 1 ruang perpustakaan. Jumlah guru kelas PNS 5 orang, Guru kelas honor APBD 5 orang, guru Agama Islam PAI 1 orang dan guru olah raga 1 orang. Berdasarkan dari data sekolah ini menunjukkan bahwa baru satu tahun didirikan SD Negeri 64/IV Kota Jambi.

\section{Gambaran Umum Subjek Penelitian}

Gambaran umum subjek penelitian ini adalah siswa kelas III SD Negeri 64/IV Kota Jambi yang berjumlah sebanyak 25 orang yang terdiri dari 16 lakilaki dan 9 perempuan. Kondisi siswa sebelum dilakukan penelitian tindakan kelas bahwa hasil belajarnya dengan rata-rata ulangan hariannya adalah 54,40 dari jumlah siswa sebanyak 25 orang. Di samping itu dari 25 orang yang tuntas hanya 4 orang, sedangkan tang tidak tuntas sebanyak 21 orang.

Pra siklus merupakan kondisi awal peserta didik sebelum peneliti melakukan kegiatan penelitian di dalam kelas dengan menggunakan pola pembelajaran konvensional atau teacher center. Selanjutnya berdasarkan hasil data pra siklus yang diperoleh melalui hasil ulangan harian peserta didik sebelumnya, terlihat masih rendahnya hasil belajar yang dicapai peserta didik tersebut. Hal ini dikarenakan proses pembelajaran yang terjadi bersifat monoton dan hanya berpusat pada guru. Sehingga tingkat partisipasi peserta didik dalam belajar masih rendah dan peseta didik kurang bersemangat dalam belajar.

Adapun hasil penilaian dari mata pelajaran Bahasa Indonesia pada membaca lancar kelas III.D SDN 64/IV rata-rata hasilnya belum mencapai KKM sekolah yaitu 68. Hasil nilai rata-rata untuk lancar hanya 54,40 dari 25 siswa kelas III.D SD Negeri 64/IV Kec. Kota Baru Jambi.

Tabel 4. Daftar Nilai Kelas I

\begin{tabular}{clcl}
\hline No & \multicolumn{1}{c}{ Nama Siswa } & Nilai & \multicolumn{1}{c}{ Kriteria } \\
\hline 1 & Ahmad Ichsan Wardana & 60 & Tidak Tuntas \\
2 & Alvia Azzahrah & 50 & Tidak Tuntas \\
3 & Andika Pratama & 70 & Tuntas \\
4 & Angela Chiesanaysilla Dasilu & 50 & Tidak Tuntas \\
5 & Fira Desty Panggabayan & 50 & Tidak Tuntas \\
6 & Aniesta Prastia & 50 & Tidak Tuntas \\
7 & Arby Satria Pratama & 50 & Tidak Tuntas \\
8 & Ariesta Sasabilah & 50 & Tidak Tuntas \\
9 & Birly Okta Vianto & 60 & Tidak Tuntas \\
10 & Claudya Cintya Bella & 40 & Tidak Tuntas \\
11 & Dhirga Teguh Samosir & 40 & Tidak Tuntas \\
12 & Dika Hamonagan Simbolar & 50 & Tidak Tuntas \\
13 & Dania Putri Octaviani & 60 & Tidak Tuntas \\
14 & Elfita Maharani & 70 & Tuntas \\
15 & Farhan Alif Maulana & 70 & Tuntas
\end{tabular}

16 Gendis Ayu Larasati

17 Karen Karisma

18 Kayla Wafi Amira

19 Latifah Nuraulia

20 M. Fortino Rewanda Adhasyah

21 M. Afif Al- Farizi

22 M. Fardhan Fadillah J

23 M. Vikri Alvarizi

24 Maria Lousie Chieli Villa Dasir

25 M. Fahr

Jumlah

Rata-Rata

Table 5. Rekapitulasi Hasil Tes Formatif pada Pra Siklus

\begin{tabular}{llc}
\hline No & \multicolumn{1}{c}{ Uraian } & Hasil \\
\hline 1 & Nilai rata-rata tes formatif & 54,40 \\
2 & Jumlah peserta didik yang tuntas belajar & 4 \\
3 & Persentase ketuntasan belajar & $16 \%$ \\
\hline
\end{tabular}

Berdasarkan tabel 5 di atas dapat dijelaskan bahwa sebelum menerapkan model pembelajaran cooperative learning make a match diperoleh nilai ratarata hasil belajar peserta didik adalah 54,40 dengan kategori kurang, dengan persentase ketuntasan belajar hanya mencapai $16 \%$ atau ada 4 dari 25 peserta didik yang tuntas belajar.

Berdasarkan kenyataan-kenyataan di atas, peneliti dibantu oleh teman sejawat melakukan kajian dan telaah yang akan dipergunakan sebagai dasar pertimbangan memilih strategi pembelajaran yang tepat, dalam upaya melakukan tindakan perbaikan pada pembelajaran Bahasa Indonesia dengan materi membaca lancar. Setelah berdiskusi dan mempertimbangkan berbagai alasan tersebut, peneliti memilih model cooperative learning tipe make a match. Model ini akan dipergunakan dalam PTK yang akan dilaksanakan pada saat berlangsungnya proses pembelajaran di kelas III SD Negeri 64/IV Kota Jambi dengan kompetensi dasar " membaca lancar". Seluruh rangkaian PTK tersebut selanjutnya dibagi menjadi beberapa tahapan, yang sering disebut dengan siklus. Penerapan siklus merupakan bagian dari tahapan sebuah PTK yang bertujuan untuk mendapatkan data penelitian.

\section{Siklus I \\ Hasil Observasi Pengelolaan Pembelajaran Guru Siklus I}

Berdasarkan hasil dari perbaikan pada pra siklus, maka setelah melakukan kegiatan observasi pengelolaan pembelajran guru pada siklus I telah dilakukan dengan model pembelajaran cooperative learning tipe make a match sesuai dengan langkahlangkah pembelajrannya. Maka hasil pengelolaan pembelajran teresbut dapat dilihat pada tabel 6 Rekapitulasi hasil observasi pengelolaan pembelajaran siklus I kelas III SD Negeri 64/IV Kota Baru Jambi 
Tabel 6. Rekapitulasi Hasil Observasi Pengelolaan Pembelajaran Siklus I

\begin{tabular}{|c|c|c|c|c|}
\hline \multirow[t]{2}{*}{ No } & \multirow[t]{2}{*}{ Aspek yang diamati } & \multicolumn{2}{|c|}{ Penilaian } & \multirow[t]{2}{*}{ Rata-rata } \\
\hline & & P1 & P2 & \\
\hline \multirow[t]{11}{*}{1} & $\begin{array}{l}\text { Pengamatan KBM } \\
\text { A. Pendahuluan }\end{array}$ & & & \\
\hline & 1. Memotivasi peserta didik & 3 & 3 & 3 \\
\hline & 2. Menyampaikan tujuan pembelajaran & 3 & 3 & 3 \\
\hline & 3. Menghubungkan dengan pelajaran yang sebelumnya & 3 & 3 & 3 \\
\hline & 4. Mengatur peserta didik dalam menggunakan kartu & 3 & 3 & 3 \\
\hline & B. Kegiatan inti & & & \\
\hline & $\begin{array}{l}\text { 1. Mempersentasekan langkah-langkah model pembelajran Cooperatif Learning Tipe } \\
\text { Make A Match }\end{array}$ & 2 & 3 & 2 \\
\hline & $\begin{array}{l}\text { 2. Membimbing peserta didik melakukan kegiatan model pembelajran Cooperatif } \\
\text { Learning Tipe Make A Match }\end{array}$ & 2 & 3 & 2 \\
\hline & $\begin{array}{l}\text { 3. Melatih keterampilan kooperatif model pembelajran Cooperatif Learning Tipe Make A } \\
\text { Match }\end{array}$ & 2 & 2 & 2 \\
\hline & 4. Mengawasi setiap kerja siswa secara individu maupun kelompok & 3 & 3 & 3 \\
\hline & 5. Memberikan bantuan kepada siswa untuk bergabung kepada kelompok lain & 2 & 2 & 2 \\
\hline II. & C. Pengelolaan waktu & 2 & 2 & 2 \\
\hline \multirow[t]{4}{*}{ III } & D. Penutup & & & \\
\hline & 1. Siwa bersama guru merangkum pembelajarn & 2 & 3 & 2.5 \\
\hline & 2. Siswa bersama guru merfleksi proses pembelajran & 2 & 3 & 2,5 \\
\hline & JUMLAH & 29 & 33 & 31 \\
\hline
\end{tabular}

Berdasarkan tabel 6 hasil observasi kegiatan pengelolaan pembelajaran guru setelah dianalisis tindakannya, maka hasil pada KBM pertemuan 1 dan 2 adalah dengan skor total dibagi dua adalah 30 , dengan persentase baru mencapai $64,59 \%$ dengan kategori cukup. Dengan demikian perlu adanya perbaikan pada siklus I untuk dapat dilanjutkan pada siklus II. Setelah dilakukan observasi maka aspek yang perlu mendapat perhatian adalah diperoleh informasi aspek-aspek yang mendapatkan kriteria cukup adalah aspek dalam penglolaan langkah-langkah pembelajran dan pengelolaan waktu yang kurang tepat. Selanjutnya dilakukan kembali proses pembelajran seperti pada siklus I, tetapi yang perlu mendapat perhatian adalah kekurangan pada hasil pengelolaan siklus I perlu ditingkatkan agar hasil siklus II mendapat peningkatan dalam peneglolaan pembelajaran oleh guru.

\section{Hasil Aktivitas Belajar Siswa Siklus I}

Analisis hasil tindakan berikutnya adalah pada penelitian hasil data yang telah dikumpulkan selama penelitian aktifitas siswa dapat dilihat pada tabel 7 adalah sebagai berikut.

Tabel 7. Hasil Observasi Aktivitas Siswa Siklus I

\begin{tabular}{|c|c|c|c|c|}
\hline No & Aktivitas Belajar Siswa & Hasil P1 \% & Hasil P2 \% & Rata-Rata P1 + P2 \\
\hline 1 & Siswa mendengarkan penjelasan guru & 71 & 80 & $75,50 \%$ \\
\hline 2 & Siswa mengamati dan memikirkan soal/jawaban kartu yang dipegangnya & 68 & 76 & $71,50 \%$ \\
\hline 3 & Siswa menyimak penjelasan guru tentang aturan penggunaan kartu & 69 & 79 & $74,00 \%$ \\
\hline 4 & Siswa yang mendapatkan kartu mencari pasangan yang cocok & 64 & 74 & $69,00 \%$ \\
\hline 5 & Siswa melakukan kerja sama dengan teman yang lain dalam menggunakan kartu & 62 & 71 & $66,50 \%$ \\
\hline 6 & Siswa membuat kesimpulan & 64 & 70 & $67,00 \%$ \\
\hline
\end{tabular}

Berdasarkan tabel 7 hasil observasi kegiatan aktivitas siswa setelah dianalisis tindakannya, maka hasil pada pertemuan 1 dan 2 adalah dengan skor total dibagi dua pada 6 aspek yang diamati, adalah sebagai berikut : 1) Aspek siswa mendengarkan penjelasan guru dengan persentase baru mencapai $75,50 \%$ dengan kategori cukup. 2) Aspek siswa mengamati dan memikirkan soal/jawaban kartu yang dipegangnya dengan persentase mencapai $71,50 \%$ kategori cukup. 3) Aspek siswa menyimak penjelasan guru tentang aturan penggunaan kartu dengan persentase mencapai $74,00 \%$ kategori cukup aktif. 4) Aspek Siswa yang mendapatkan kartu mencari pasangan yang cocok dengan persentase mencapai 69,00\% kategori kurang aktif. 5 Aspek siswa melakukan kerja sama dengan teman yang lain dalam menggunakan kartu persetase adalah 66,50 kategori kurang aktif dan 6) Aspek siswa membuat kesimpulan hasil mencapai $67,00 \%$ kategori kurang aktif. Dengan demikian perlu adanya perbaikan pada siklus I untuk dapat dilanjutkan pada siklus II. Hasil yang perlu ditingkatkan pada siklus II adalah pada aspek 4,5, dan 6 karena ketiga aspek tersebut hasilnya masih kurang.

\section{Hasil Tes Peserta Didik Siklus I}

Berdasarkan dari pengelolaan pembelajaran dan aktivitas siswa dalam kegiatan belajar mengajar, maka rekapitulasi hasil tes siswa dapat dilihat pada tabel 8 berikut:

Tabel 8. Rekapitulasi Hasil Tes Pertemuan 1 dan 2 Siklus I

\begin{tabular}{llccc}
\hline No & \multicolumn{1}{c}{ Nama Siswa } & Nilai P1 & Nilai P2 & Rata-Rata P1+P2 : 2 \\
\hline 1 & Ahmad Ichsan Wardana & 70 & 80 & 75 \\
2 & Alvia Azzahrah & 70 & 70 & 70 \\
3 & Andika Pratama & 80 & 80 & Tuntas \\
4 & Angela Chiesanaysilla Dasilu & 70 & 70 & 70 \\
5 & Fira Desty Panggabayan & 50 & 60 & 70 \\
6 & Aniesta Prastia & 50 & 60 & 55 \\
\end{tabular}




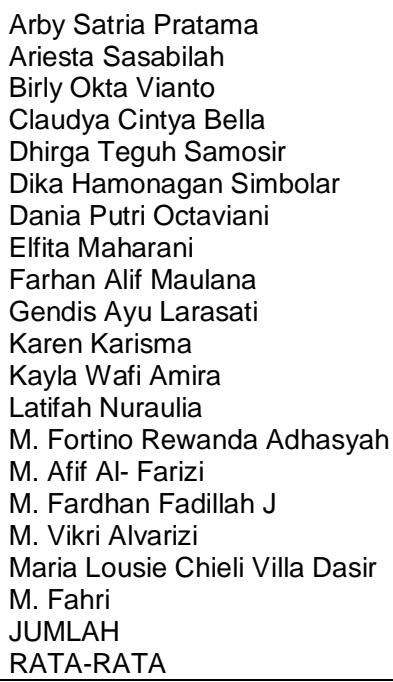

$\begin{array}{rr}50 & 60 \\ 68 & 70 \\ 70 & 75 \\ 50 & 50 \\ 50 & 60 \\ 70 & 70 \\ 70 & 70 \\ 80 & 80 \\ 70 & 80 \\ 50 & 60 \\ 80 & 80 \\ 70 & 70 \\ 50 & 60 \\ 68 & 70 \\ 50 & 50 \\ 70 & 80 \\ 70 & 70 \\ 50 & 60 \\ 50 & 50 \\ 1576 & 1685 \\ 63,04 & 67,40\end{array}$

\begin{tabular}{cc}
55 & \multicolumn{2}{c}{ Tidak Tuntas } \\
69 & Tuntas \\
72,5 & Tuntas Tidak Tuntas \\
50 & \multicolumn{2}{c}{ Tidak Tuntas } \\
55 & Tuntas \\
70 & Tuntas \\
70 & Tuntas \\
80 & Tuntas \\
75 & \multicolumn{2}{c}{ Tidak Tuntas } \\
55 & Tuntas \\
80 & Tuntas Tidak Tuntas \\
70 & \multicolumn{2}{c}{ Tidak Tuntas } \\
55 & Tuntas \\
69 & Tuntas \\
50 & Tuntas Tidak Tuntas \\
75 & \multicolumn{2}{c}{ Tidak Tuntas } \\
70 & \\
55 & \\
50 &
\end{tabular}

Tabel 9. Rekapitulasi Hasil Tes pada Siklus I

\begin{tabular}{lll}
\hline No & \multicolumn{1}{c}{ Uraian } & \multicolumn{1}{c}{ Hasil } \\
\hline 1 & Nilai rata-rata tes formatif & 65,22 \\
2 & Jumlah peserta didik yang tuntas belajar & 15 \\
3 & Persentase ketuntasan belajar & $60 \%$
\end{tabular}

Berdasarkan tabel 9 bahwa rekapitulasi hasil tes belajar siswa pada siklus I dapat dijelaskan bahwa sebelum menerapkan model pembelajaran cooperative learning make a macth diperoleh nilai rata-rata hasil belajar peserta didik adalah 65,22 dengan kategori cukup, sedangkan persentase ketuntasan belajar mencapai $70,58 \%$ atau ada 24 peserta didik dari 34 siswa.

\section{Hasil Siklus II \\ Hasil Observasi Pengelolaan Pembelajaran Guru Siklus II}

Berdasarkan hasil dari perbaikan pada pra siklus, maka setelah melakukan kegiatan observasi pengelolaan pembelajaran guru pada siklus I telah dilakukan dengan model pembelajaran cooperative learning tipe make a match sesuai dengan langkahlangkah pembelajarannya. Maka hasil pengelolaan pembelajran teresbut dapat dilihat pada table 10 . Rekapitulasi hasil observasi pengelolaan pembelajaran siklus II kelas III SD Negeri 64/IV Kota Baru Jambi

Tabel 10. Rekapitulasi Hasil Observasi Pengelolaan Pembelajaran Siklus II

\begin{tabular}{|c|c|c|c|c|}
\hline \multirow[t]{2}{*}{ No } & \multirow[t]{2}{*}{ Aspek yang diamati } & \multicolumn{2}{|c|}{ Penilaian } & \multirow[t]{2}{*}{ Rata-rata } \\
\hline & & P1 & P2 & \\
\hline \multirow[t]{11}{*}{1} & $\begin{array}{l}\text { Pengamatan KBM } \\
\text { A. Pendahuluan }\end{array}$ & & & \\
\hline & 1. Memotivasi peserta didik & 4 & 4 & 44 \\
\hline & 2. Menyampaikan tujuan pembelajaran & 4 & 4 & 4 \\
\hline & 3. Menghubungkan dengan pelajaran yang sebelumnya & 4 & 4 & 4 \\
\hline & 4. Mengatur peserta didik dalam menggunakan kartu & 4 & 4 & 4 \\
\hline & B. Kegiatan inti & & & \\
\hline & $\begin{array}{l}\text { Mempersentasekan langkah-langkah model pembelajran Cooperatif Learning Tipe Make A } \\
\text { Match }\end{array}$ & 3 & 3 & 4 \\
\hline & $\begin{array}{l}\text { Membimbing peserta didik melakukan kegiatan model pembelajran Cooperatif Learning } \\
\text { Tipe Make A Match }\end{array}$ & 3 & 4 & 3,5 \\
\hline & Melatih keterampilan kooperatif model pembelajran Cooperatif Learning Tipe Make A Match & 3 & 4 & 3,5 \\
\hline & Mengawasi setiap kerja siswa secara individu maupun kelompok & 3 & 4 & 3,5 \\
\hline & Memberikan bantuan kepada siswa untuk bergabung kepada kelompok lain & 3 & 4 & 3,5 \\
\hline \multirow{5}{*}{$\begin{array}{l}\text { II. } \\
\text { III }\end{array}$} & C. Pengelolaan waktu & 4 & 4 & 4 \\
\hline & D. Penutup & & & \\
\hline & 1. Siwa bersama guru merangkum pembelajarn & 4 & 3 & 3.5 \\
\hline & 2. Siswa bersama guru merfleksi proses pembelajran & 4 & 3 & 3,5 \\
\hline & JUMLAH & 41 & 45 & 43 \\
\hline
\end{tabular}

Berdasarkan tabel diatas hasil observasi kegiatan pengelolaan pembelajaran guru setelah dianalisis tindakannya, maka hasil pada siklus KBM pertemuan 1 dan 2 adalah dengan skor total dibagi dua adalah 43 , dengan persentase mengalami peningkatan sangat signifikan yaitu $89,53 \%$ dengan sangat baik. Maka dari itu bahwa hasil pada siklus II ini sudah menunjukkan hasilnya sangat sangat baik bahwa model pembelajaran cooperative learning make a match dapat meningkatkan hasil belajar membaca lancar pada siswa kelas III SD Negeri 64/IV Kecamatan Kota Baru Jambi pada semester genap tahun pelajaran 2017/2018.

\section{Hasil Aktivitas Belajar Siswa Siklus II}

Analisis hasil tindakan berikutnya adalah pada penelitian hasil data yang telah dikumpulkan selama penelitian aktivitas siswa dapat dilihat pada tabel 11 adalah sebagai berikut. 
Tabel 11. Hasil Observasi Aktivitas Siswa Siklus II

\begin{tabular}{|c|c|c|c|c|}
\hline No. & Aktivitas Belajar Siswa & Hasil P1 \% & Hasil P2 \% & Rata-Rata P1 + P2 \\
\hline 1 & Siswa mendengarkan penjelasan guru & 90 & 95 & $92,50 \%$ \\
\hline 2 & Siswa mengamati dan memikirkan soal/jawaban kartu yang dipegangnya & 90 & 96 & $93,00 \%$ \\
\hline 3 & Siswa menyimak penjelasan guru tentang aturan penggunaan kartu & 92 & 97 & $94,50 \%$ \\
\hline 4 & Siswa yang mendapatkan kartu mencari pasangan yang cocok & 97,00 & 97,00 & $99,00 \%$ \\
\hline 5 & Siswa melakukan kerja sama dengan teman yang lain dalam menggunakan kartu & 90,00 & 90,00 & $90,00 \%$ \\
\hline 6 & Siswa membuat kesimpulan & 88,00 & 88,00 & $88,00 \%$ \\
\hline
\end{tabular}

Berdasarkan tabel diatas hasil observasi kegiatan aktivitas siswa setelah dianalisis tindakannya, maka hasil pada pertemuan 1 dan 2 adalah dengan skor total dibagi dua pada 6 aspek yang diamati, adalah sebagai berikut : 1) Aspek siswa mendengarkan penjelasan guru dengan persentase baru mencapai 92,50\% dengan kategori sangat aktif. 2) Aspek siswa mengamati dan memikirkan soal/jawaban kartu yang dipegangnya dengan persentase mencapai $93,00 \%$ kategori sangat aktif. 3) Aspek siswa menyimak penjelasan guru tentang aturan penggunaan kartu dengan persentase mencapai 94,50\% kategori sangat aktif. 4) Aspek Siswa yang mendapatkan kartu mencari pasangan yang cocok dengan persentase mencapai $97,00 \%$ kategori sangat aktif. 5 Aspek siswa melakukan kerja sama dengan teman yang lain dalam menggunakan kartu persetase adalah 90,00 kategori sangat aktif dan 6) Aspek siswa membuat kesimpulan hasil mencapai $88,00 \%$ kategori sangat aktif. Berdasarkan hasil analisi data pada siklus II sudah mencapai nilai sudah mencapai indicator keberhasilannya maka hanya dilakukan pada siklus II.

\section{Hasil Tes Peserta Didik Siklus II}

Berdasarkan dari pengelolaan pembelajaran dan aktivitas siswa dalam kegiatan belajar mengajar, maka rekapitulasi hasil tes siswa dapat dilihat pada tabel 12 berikut:

Tabel 12. Rekapitulasi Hasil Tes Pertemuan 1 dan 2 Siklus II

\begin{tabular}{clcccc}
\hline No & \multicolumn{1}{c}{ NAMA SISWA } & Nilai P1 & Nilai P2 & Rata-Rata P1+P2:2 & Kriteria \\
\hline 1 & Ahmad Ichsan Wardana & 80 & 90 & 85 & Tuntas \\
2 & Alvia Azzahrah & 80 & 80 & 80 & Tuntas \\
3 & Andika Pratama & 90 & 90 & 90 & Tuntas \\
4 & Angela Chiesanaysilla Dasilu & 80 & 80 & 80 & Tuntas \\
5 & Fira Desty Panggabayan & 70 & 70 & 70 & Tuntas \\
6 & Aniesta Prastia & 60 & 80 & 75 & Tidak \\
7 & Arby Satria Pratama & 80 & 80 & 80 & Tidak \\
8 & Ariesta Sasabilah & 70 & 80 & 75 & Tuntas \\
9 & Birly Okta Vianto & 80 & 90 & 85 & Tuntas \\
10 & Claudya Cintya Bella & 80 & 80 & 80 & Tidak \\
11 & Dhirga Teguh Samosir & 80 & 90 & 85 & Tidak \\
12 & Dika Hamonagan Simbolar & 90 & 90 & 90 & Tuntas \\
13 & Dania Putri Octaviani & 90 & 90 & 90 & Tuntas \\
14 & Elfita Maharani & 80 & 90 & 85 & Tuntas \\
15 & Farhan Alif Maulana & 80 & 90 & 70 & Tuntas \\
16 & Gendis Ayu Larasati & 70 & 70 & 90 & Tuntas \\
17 & Karen Karisma & 90 & 90 & 80 & Tuntas \\
18 & Kayla Wafi Amira & 80 & 80 & 80 & Tuntas \\
19 & Latifah Nuraulia & 80 & 80 & 80 & Tuntas \\
20 & M. Fortino Rewanda Adhasyah & 80 & 80 & 60 & Tuntas \\
21 & M. Afif Al- Farizi & 60 & 60 & 85 & Tidak Tuntas \\
22 & M. Fardhan Fadillah J & 80 & 90 & 80 & Tuntas \\
23 & M. Vikri Alvarizi & 80 & 80 & 80 & Tuntas \\
24 & Maria Lousie Chieli Villa Dasir & 80 & 80 & 60 & Tuntas \\
25 & M. Fahri & 60 & 60 & 2000 & Tidak Tuntas \\
& JUMLAH & 1950 & 2040 & 79,80 & \\
\hline
\end{tabular}

Table 13. Rekapitulasi Hasil Tes pada Siklus II

\begin{tabular}{lll}
\hline No & Uraian & Hasil \\
\hline 1 & Nilai rata-rata tes formatif & 79,80 \\
2 & Jumlah peserta didik yang tuntas belajar & 23 \\
3 & Persentase ketuntasan belajar & $92 \%$ \\
\hline
\end{tabular}

Berdasarkan tabel 13 bahwa rekapitulasi hasil tes belajar siswa pada siklus I dapat dijelaskan bahwa sebelum menerapkan model pembelajaran cooperative learning make a macth diperoleh nilai rata-rata hasil belajar peserta didik adalah $79,80 \%$ dengan kategori baik, sedangkan persentase ketuntasan belajar mencapai $92,00 \% \%$ atau ada 24 peserta didik dari 25 siswa.

\section{Pembahasan}

Pembahasan Hasil Penelitian dari hasil penelitian siklus I baik pengelolaan pembelajaran, aktivitas siswa dan hasil membaca lancar belajar siswa yang dilaksanakan diperoleh hasil yang belum memuaskan. Pada siklus I dalam pengelolaan pembelajaran guru melaksanakannya masih dalam kategori cukup. Terdapat beberapa kelemahan dengan menggunakan model pembelajaran cooperative learning make a match, Guru belum makimal mempersentasekan langkahlangkah model pembelajaran Cooperatif Learning Tipe Make A Match dengan baik. Langkah-langkah kegaiatn guru adalah dalam membimbing peserta didik melakukan kegiatan model pembelajaran Cooperatif Learning Tipe Make a Match. Melatih keterampilan 
kooperatif model pembelajran Cooperatif Learning Tipe Make A Match, Mengawasi setiap kerja siswa secara individu maupun kelompok. Jadi dengan demikian model make a match terbukti dapat meningkatkan hasil belajar siswa melalui coopertaif learning model make a match.

Berdasarkan penelitian yang dilakukan oleh Diah Hastami berjudul "Upaya Meningkatkan Kemampuan Membaca Lancar dengan Menerapkan Model Pembelajaran Cooperative Learning Tipe Make a Match Siswa Kelas III Semester 2 SD Negeri 64/IV Kota Baru Jambi" hasil penelitian menunjukkan siklus I keterampilan guru, aktivitas siswa, dan hasil belajar siswa mendapatkan prosentase ketuntasan mencapai $61,2 \%$. Pada siklus II keterampilan guru, aktivitas siswa , hasil belajar siswa memperoleh presentase ketuntasan mencapai $86,1 \%$, pada siklus III keterampilan guru, aktivitas siswa, dan hasil belajar siswa, memeperoleh ketuntasan hasil belajar siswa pada siklus III mencapai $94,4 \%$.

Berdasarkan penelitian yang dilakukan oleh Mariani berjudul "Upaya Meningkatkan Kemampuan Membaca Lancar dengan Menerapkan Model Pembelajaran Cooperative Learning Tipe Make a Match Siswa Kelas III Semester 2 SD Negeri 64/IV Kota Baru Jambi" hasil penelitian menunjukkan Aktivitas guru mengalami peningkatan pada siklus I yakni $70,83 \%$ kategori baik meningkat pada pelaksanaan siklus II yang mencapai persentase $(95,83 \%)$ dengan kategori sangat baik. Dari hasil pengamatan yang dilakukan oleh observer pada siklus II, guru telah melakukan seluruh aktivitas dengan baik sesuai dengan langkah-langkah dengan menggunakan media kartu. Seiring dengan meningkatnya aktivitas guru pada siklus II, aktivitas siswa juga meningkat, di mana pada siklus I aktivitas siswa hanya memperoleh persentase $(71,67 \%)$ dan meningkat menjadi $(86,67 \%)$ dengan kategori baik sekali. Motivasi belajar siswa juga terlihat meningkat. Hal ini terbukti dari persentase motivasi belajar siswa pada siklus I yang hanya memperoleh persentase $75,00 \%$ dengan kategori baik, meningkat menjadi persentase $83,75 \%$ dengan kategori baik sekali.

Berdasarkan hasil pembahasan tersebut menunjukkan bahwa dengan menggunakan model pembelajaran cooperative learning tipe make a match yang diterapkan dalam pembelajaran dapat memberikan hasil belajar siswa dalam membaca lancar sehingga materi pembelajaran yang disampaikan menjadi lebih menarik bagi siswa. Dengan hasil belajar membaca lancar siswa pada siklus II ini, penelitian tindakan kelas dengan menggunakan model pembelajaran cooperative learning tipe make a match hanya dilakukan dua siklus saja, karena indikator kinerja sudah tercapai.

Berdasarkan hasil penelitian siklus I dan II baik penngelolaan pembelajaran guru maupun aktivitas siswa menggunakan model cooperative learning maka hal ini mempengaruhi peningkatan pada aktivitas siswa dan hasil belajar siswa. Berdasarkan pembahasan penelitian di atas, berkaitan dengan penggunaan model pembelajaran coopertaif learning make a match, maka ada beberapa saran yang perlu dipertimbangkan pada penelitian teresbut.

\section{SIMPULAN}

Berdasarkan dari hasil pengolahan dan analisis data, maka dari hasil perbaikan pembelajaran telah dilaksanakan dapat ditarik kesimpulan yaitu sebagai berikut: Proses pembelajaran Bahasa Indonesia dengan membaca lancar harus didasarkan pada penguasaan materi dan model pembelajaran cooperatif learning make a match dapat meningkatkan kemampuan membaca lancar pada siswa kelas III.D SDN 64/IV Kota Jambi.

Peningkatan hasil belajar dan aktivitas siswa akan mengalami peningkatan dalam membaca lancar bagi siswa kelas III.D SD 64/IV Kota Jambi. Peningkatan tersebut pada siklus I pada pengelolaan pembelajaran 64,59 sedangkan pada siklus II mengalami peningkatan yaitu menjadi $89,53 \%$ kategori sangat baik. Apabila pengelolaannya sangat baik tentu mempengaruhi hasil belajr dan aktivtas siswa yaitu siklus I aktivitas siswa 70,58 kategori cukup sedangkan siklus II mengalamai peningkatan menjadi 92,83 kategori dengan sangat baik. Selanjutnya untuk hasil belajar pada siklus I 65,22 kategori cukup sedangkan siklus II mengalami peningktan menjadi 79,80 kategori baik.

\section{DAFTAR PUSTAKA}

Akhadiah, Sabarti dkk (1991) pembinaan kemampuan menulis bahasa Indnesia. Jakarta: Erlangga

Anita Lie. 2002. Cooperative Learning. Jakarta : Gramedia Widiasarana Indonesia.

Dimyati dan Mudjiono. 2009. Belajar dan Pembelajaran. Jakarta: PT. Rineka Cipta.

Huda, Miftahul. 2011. Cooperative Learning: Metode, Teknik, Struktur dan Model Penerapan. Pustaka Pelajar. Yogyakarta.

Isjoni. 2007. Cooperative Learning: Efektifitas Pembelajaran Kelompok. Bandung: Alfabeta.

Komalasari, Kokom. 2010. Pembelajaran Kontekstual: Konsep dan Aplikasi. Refika Aditama. Bandung.

Muchlisnoh. 1992. Tujuan membaca. Malang: Tiga serangkai

Nana Sudjana 2010. Dasar-dasar Proses Belajar, Sinar Baru Bandung

Poerwadarminta, W.J.S. 1990. Kamus Besar Bahasa Indonesia. Balai Pustaka, Jakarta. 